OPEN

SUBJECT AREAS:

DRUG DEVELOPMENT

MALARIA

ENZYME MECHANISMS

MECHANISM OF ACTION

Received

1 October 2013

Accepted

10 December 2013

Published

9 January 2014

Correspondence and requests for materials should be addressed to S.V.A. (Simon.Avery@ nottingham.ac.uk)

* Current address: Faculty of Pharmacy, University of

Kebangsaan

Malaysia, 50300,

Kuala Lumpur,

Malaysia.

\section{The antimalarial drug quinine interferes with serotonin biosynthesis and action}

\author{
Farida Islahudin ${ }^{1,2 *}$, Sarah M. Tindall' , lan R. Mellor' ${ }^{1}$, Karen Swift' ${ }^{1}$, Hans E. M. Christensen ${ }^{3}$, \\ Kevin C. F. Fone' ${ }^{1}$, Richard J. Pleass ${ }^{4}$, Kang-Nee Ting ${ }^{5}$ \& Simon V. Avery ${ }^{1}$
}

'School of Life Sciences, University of Nottingham, Nottingham NG7 2RD, UK, ${ }^{2}$ School of Pharmacy, University of Nottingham Malaysia Campus, 43500 Semenyih, Malaysia, ${ }^{3}$ Department of Chemistry, Technical University of Denmark, DK-2800 Kgs. Lyngby, Denmark, ${ }^{4}$ University of Liverpool, Liverpool School of Tropical Medicine, Liverpool L3 5QA, UK, ${ }^{5}$ School of Life Sciences, University of Nottingham Malaysia Campus, 43500 Semenyih, Malaysia.

The major antimalarial drug quinine perturbs uptake of the essential amino acid tryptophan, and patients with low plasma tryptophan are predisposed to adverse quinine reactions; symptoms of which are similar to indications of tryptophan depletion. As tryptophan is a precursor of the neurotransmitter serotonin (5-HT), here we test the hypothesis that quinine disrupts serotonin function. Quinine inhibited serotonin-induced proliferation of yeast as well as human (SHSY5Y) cells. One possible cause of this effect is through inhibition of 5-HT receptor activation by quinine, as we observed here. Furthermore, cells exhibited marked decreases in serotonin production during incubation with quinine. By assaying activity and kinetics of the rate-limiting enzyme for serotonin biosynthesis, tryptophan hydroxylase (TPH2), we showed that quinine competitively inhibits TPH2 in the presence of the substrate tryptophan. The study shows that quinine disrupts both serotonin biosynthesis and function, giving important new insight to the action of quinine on mammalian cells.

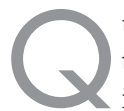

uinine $(\mathrm{QN})$ has been a mainstay drug in the battle against malaria, which is responsible for the loss of up to one million human lives each year ${ }^{1}$. However, QN efficacy as an antimalarial has been limited by some incidence of drug resistance ${ }^{2}$ and by common adverse reactions among patients $\mathrm{s}^{3,4}$. Adverse reactions also impact the application of quinine as a treatment for leg cramps. The basis for these adverse reactions is poorly understood, but recent research has shed some new light on the issue. Studies using a model organism, the yeast Saccharomyces cerevisiae, revealed that transport of the essential amino acid tryptophan is inhibited by $\mathrm{QN}^{5}$. As a result, QN causes tryptophan starvation, a toxic mode of action that can be suppressed in media with high tryptophan $^{5,6}$. The relevance of these findings to humans has been highlighted in clinical screens of malaria patients treated with $\mathrm{QN}^{7}$. This demonstrated that patients with lower plasma tryptophan were more likely to experience adverse reactions to QN, undermining its safety profile. This is important as tryptophan levels in humans vary considerably between individuals ${ }^{8,9}$. Such differences are at least partly due to diet and, therefore, dietary supplements could offer a simple way to manipulate QN responses in patients ${ }^{7}$.

This inter-relationship between QN and tryptophan resonates with an overlap in certain symptoms of tryptophan depletion and adverse QN reactions (cinochonism) in humans, such as tinnitus, anxiety and sleep disturbance $^{8-12}$. The fact that neuropsychological effects are among these overlapping contra-indications is notable, as tryptophan is a metabolic precursor for the neurotransmitter serotonin (5-hydroxytryptamine, 5-HT). Indeed, tryptophan depletion results in decreased serotonin production ${ }^{13}$ and can trigger depression in susceptible individuals as discussed below.

The dysregulation of the monoamine serotonin in the brain has been extensively studied and has been linked to many psychiatric disorders ${ }^{14}$. Neuropsychological indications such as weakened decision making, poor mood or sleep, pain, appetite and depression have all been linked to serotonin function ${ }^{14-16}$. Serotonin in organisms is synthesised from tryptophan through two enzymatic reactions. The rate limiting reaction is catalysed by tryptophan hydroxylase (TPH), which converts tryptophan to the intermediate 5-hydroxytryptophan. Tryptophan hydroxylase-2 (TPH2) performs this function in the central nervous system, while another isoform, TPH1, does so in the periphery. Serotonin is subsequently produced from 5-hydroxytryptophan by aromatic amino acid decarboxylase. Serotonin production is dependent on tryptophan availability, which hinges partly on tryptophan transport across the blood-brain barrier ${ }^{17}$. Tryptophan is transported into the brain by the large neutral amino acid (LNAA) transporter, in competition with several other amino acids. Such interactions make tryptophan 
metabolism difficult to predict. However, perturbation of tryptophan availability has the potential to disrupt normal neuropsychological performance. For example, acute tryptophan depletion in patients with a history of depression and panic disorders can cause relapse of the disorder ${ }^{18}$. Tryptophan deficiency is common in malnourished populations in Africa, where QN is still routinely used as a treatment for severe malaria.

As QN affects tryptophan availability and patients with low tryptophan appear predisposed to adverse quinine reactions $s^{5,7}$, here we hypothesize that such adverse effects of the drug could reflect perturbation of serotonin function. It has been noted previously that QN interacts at $5-\mathrm{HT}_{3}$ receptors ${ }^{19,20}$. We exploit the yeast model in conjunction with mammalian cells and biochemical assays to show that QN can inhibit both serotonin production and function.

\section{Results}

Quinine inhibits stimulation of yeast growth by serotonin. Previously it was shown that QN and tryptophan compete for uptake in yeast ${ }^{5}$, and elsewhere that the tryptophan derivative serotonin can stimulate yeast growth ${ }^{21}$. We exploited these insights in some preliminary tests for interference of serotonin action by QN, using the yeasts $C$. albicans and $S$. cerevisiae. The growth yield for $C$. albicans and $S$. cerevisiae was increased significantly in the presence of $1 \mathrm{mM}$ serotonin, by 1.7 -fold and 1.4-fold respectively (t-test, $\mathrm{p}<$ 0.0001 in both organisms) (Fig. 1). This indication of growth stimulation by serotonin was partly suppressed by the inclusion of $1 \mathrm{mM}$ QN in the medium (t-test, $\mathrm{p}=0.0017$ and 0.0043 in $C$. albicans and S. cerevisiae, respectively). When supplied alone QN had no inhibitory effect on yeast growth at this concentration, as also reported previously ${ }^{5}$. Therefore, QN specifically blocked serotoninstimulated growth.
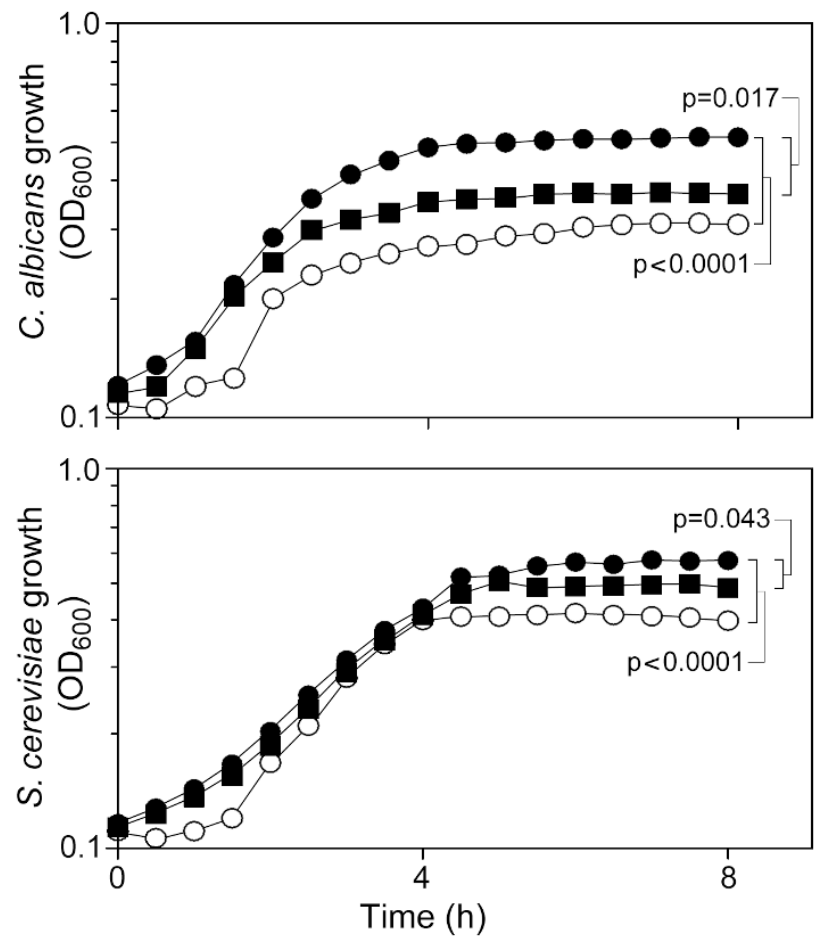

Figure $1 \mid$ Quinine inhibits stimulation of yeast growth by serotonin. $C$. albicans SC5314 (upper panel) or S. cerevisiae BY4743 (lower) were cultured in unsupplemented Sabouraud's medium $(\bigcirc)$ or medium supplemented with $1 \mathrm{mM}$ serotonin $(\mathbf{O})$, or $1 \mathrm{mM}$ serotonin $+1 \mathrm{mM}$ QN ( $\mathbf{\square})$. (This concentration of QN has no inhibitory effect on yeast growth when supplied alone ${ }^{5}$ ). Points are means from three independent experiments. SEMs were smaller than the dimensions of the symbols.
Quinine inhibits human type 2 serotonin-receptor activation. It was hypothesized that the inhibition by QN of serotonin action on yeast growth might reflect an interaction between these structurallyrelated molecules at one or more cell receptors. Previously, QN was found to block activation of heterologously-expressed mammalian 5$\mathrm{HT}_{3}$ receptors ${ }^{19,20}$. To support and extend that finding, here the effect of QN was tested in a human neuroblastoma cell line (SHSY5Y) which expresses $5-\mathrm{HT}_{2 \mathrm{a} / 2 \mathrm{c}}$ receptors, by measuring the level of cellular calcium release in response to serotonin addition. Calcium release (traced with the FLUO-4 probe) was markedly stimulated by $1 \mu \mathrm{M}$ serotonin (Fig. 2). The known potent $5-\mathrm{HT}_{2}$ receptor antagonist, ketanserin, was used as a positive control. Ketanserin effectively blocked calcium release by serotonin addition (Fig. 2). At a concentration equimolar with serotonin, QN had negligible effect on receptor activation. However, at $20 \mu \mathrm{M} \mathrm{QN}$, the response to serotonin was decreased by $\sim 30 \%$ ( $\mathrm{t}$-test, $\mathrm{p}=0.015$ ) and there was no discernible response to serotonin in the presence of $200 \mu \mathrm{M} Q N$.

Quinine inhibits stimulation of neuroblastoma cell growth by serotonin. Having corroborated that QN interferes with serotonin receptors on mammalian cells, we sought to test whether the observed inhibition of serotonin-stimulated growth of yeast cells (Fig. 1) was also apparent in mammalian cells. Previously, low concentrations of serotonin have been reported to promote growth of tumorigenic human cells lines ${ }^{22}$. In the present work, it was found that $1 \mu \mathrm{M}$ serotonin stimulated SHSY5Y cell proliferation by $\sim 14 \%$ ( $\mathrm{t}$-test, $\mathrm{p}=0.016$ ) (Fig. 3). The inclusion of $0.1 \mu \mathrm{M}$ ketanserin blocked this effect of serotonin. Similarly, and as in yeast, the presence of QN $(10 \mu \mathrm{M})$ reversed the growth stimulatory effect of serotonin (Fig. 3). Neither $0.1 \mu \mathrm{M}$ ketanserin nor $10 \mu \mathrm{M}$ QN affected cell proliferation when supplied alone.

Quinine inhibits serotonin production. Having established that QN interferes with certain serotonin functions (above), we hypothesized that the antimalarial may also perturb serotonin biosynthesis as the pathway commences with tryptophan, with which QN competes ${ }^{5}$. Serotonin production was investigated first in yeast cells transformed with pYES-TDC. This plasmid harbours a tryptophan decarboxylase gene from rice, which produces serotonin from endogenous 5-hydroxy-tryptophan in yeast, so providing a yeast model for serotonin biosynthesis ${ }^{23}$. Determination of serotonin levels in the yeast cells by HPLC-ED showed that serotonin production was decreased significantly when cells were cultured in the presence of $2 \mathrm{mM}(\mathrm{t}$-test, $\mathrm{p}=0.0082)$ or $4 \mathrm{mM}(\mathrm{p}=0.0069) \mathrm{QN}$ (Fig. 4a). These concentrations were sub-inhibitory and mildly inhibitory to growth, respectively, but there was a $\geq 90 \%$ decrease in serotonin production in both cases.

The effect of QN on serotonin production was subsequently examined in the rat raphe RN46A cell line, which expresses TPH2 activity and naturally produces serotonin. As a positive control, the known TPH2 inhibitor, p-chlorophenylalanine (pCPA), was shown to decrease serotonin levels significantly at pCPA concentrations greater than $10 \mu \mathrm{M}$ (Fig. 4b). In the case of QN, there was a decrease in cellular serotonin production with increased QN concentration. RN46A cells treated with $2 \mathrm{mM}$ QN exhibited significantly lower serotonin levels, at $65 \%$ of the amounts determined in control cells (Fig. 4c). There was some growth inhibition of the RN46A cells at this QN concentration, but this was normalized by expressing serotonin amounts on a per cell basis.

High levels of quinine uptake by RN46A cells are not affected by tryptophan supply. As QN inhibited serotonin production more strongly in yeast than in the rat RN46A cells (Fig. 4), we hypothesized that the yeast cells may take up more QN. To test this, [9- $\left.{ }^{3} \mathrm{H}\right]-\mathrm{QN}$ uptake was compared in the two cell types. Contrary to the hypothesis, QN uptake was much greater in the RN46A cells than in yeast (t-test, $\mathrm{p}=0.006$ ) (Fig. $5 a$ ). To explore QN uptake further in 


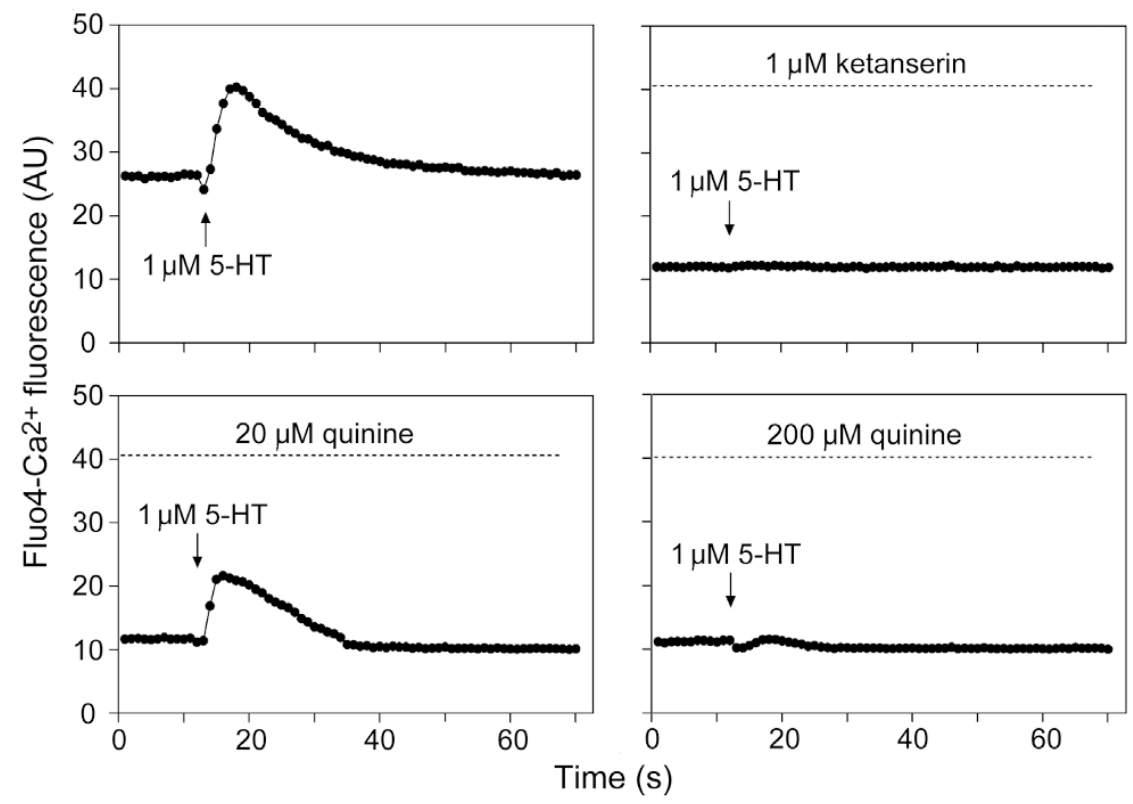

Figure $2 \mid$ Quinine inhibits 5- $\mathrm{HT}_{2}$ receptor activation. Stimulation of calcium release from SHSY5Y cells by $1 \mu \mathrm{M}$ serotonin addition was tested in the absence or presence of ketanserin or quinine at the indication concentrations. Mean data are shown from three independent experiments. AU, arbitrary units.

the rat cell line, the effect of excess tryptophan was measured. In contrast to previous work with yeast ${ }^{5}$, tryptophan addition did not affect QN uptake by RN46A cells (Fig. 5b) suggesting a distinct transport mechanism for QN in the rat cells.

Quinine competitively inhibits tryptophan hydroxylase 2. As the impact of QN on serotonin production is influenced by cell type (Fig. 4), and presumably also by in vitro experimental conditions for cells, we tested the action of QN directly on the main ratelimiting enzyme for serotonin biosynthesis, tryptophan hydroxylase 2 (TPH2). TPH2 catalyzes the synthesis of 5-hydroxytryptophan from tryptophan. The activity of the purified catalytic domain of human TPH $2^{24}$ was assayed over a range of tryptophan (substrate) concentrations in the absence or presence of QN or pCPA. The data conformed to Michaelis-Menten kinetics, and revealed that increasing the concentration of QN from $0 \mathrm{mM}$ to $2 \mathrm{mM}$ then to $10 \mathrm{mM}$ progressively decreased the TPH2 activity (Fig. $6 a$ ). Linearisation of the data to produce Lineweaver-Burk plots indicated that QN competitively inhibited TPH2 activity (as it was the

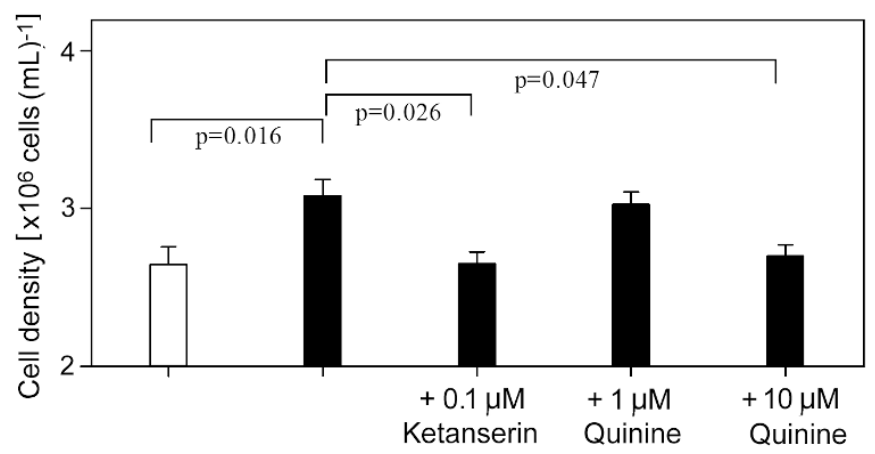

Figure 3 Quinine inhibits stimulation of neuroblastoma cell growth by serotonin. SHSY5Y cells were cultured in the absence $(\square)$ or presence ( $\square$ ) of $1 \mu \mathrm{M}$ serotonin, with ketanserin or quinine supplied at the indicated concentrations where specified. Cell density was determined after $72 \mathrm{~h}$ incubation. Mean data \pm SEM are shown from three independent experiments. intercept with the $\mathrm{x}$ axis $\left(-1 / K_{m}\right)$ that was primarily affected by QN concentration). A similar outcome was obtained for the competitiveinhibitor of TPH2, pCPA, as a positive control (Supplementary Fig. $\mathrm{S} 1 a)$. The data indicate that, like $\mathrm{pCPA}, \mathrm{QN}$ competes with tryptophan for binding to the active site of TPH2. The effects of QN and pCPA were also assayed over varying concentrations of a co-factor required for TPH2 activity, 6-methyltetrahydropterin $\left(6 \mathrm{MePH}_{4}\right)$. In this case, and in contrast to the interaction with tryptophan, altering the $\mathrm{QN}$ or pCPA concentrations gave noncompetitive inhibition of $\left(6 \mathrm{MePH}_{4}\right.$-dependent) $\mathrm{TPH} 2$ activity (Fig. $6 b$ and Supplementary Fig. S1b). This result was consistent with the role of $6 \mathrm{MePH}_{4}$ as the enzyme co-factor, and reinforced the distinctive competitive nature of the interaction between QN and the substrate tryptophan.

\section{Discussion}

The key novel findings in this paper are that the antimalarial drug quinine can interfere with both production and function of the major neurotransmitter serotonin. This could help to explain certain adverse reactions to QN treatment seen among malaria patients, particularly those with low dietary tryptophan ${ }^{3,4,7}$. The results also raise the possibility that quinine could find application as an antidote against serotonin syndrome, a condition linked to excessive serotonin in patients ${ }^{25}$. As discussed below, the effect of QN on serotonin production could be attributable to competition between the drug and tryptophan (the substrate for serotonin biosynthesis) at two principal sites: the active site of the rate-limiting enzyme for serotonin biosynthesis (TPH), and transporters responsible for tryptophan uptake by cells.

To assay potential interactions between QN and serotonin function, we exploited previous reports of serotonin-induced cell proliferation in yeast and tumorigenic cells ${ }^{21,22,26,27}$, as well as the availability of 5- $\mathrm{HT}_{2 \mathrm{a}, 2 \mathrm{c}}$ receptor-expressing cells. Aromatic alcohols act as autoinducers of yeast and tumorigenic cell growth. In nitrogen deficient media, tryptophol, an amino alcohol and tryptophan derivative is synthesized to autoinduce cell proliferation ${ }^{21}$. Because of the structural similarity between serotonin and tryptophol, serotonin can act as an autoinducer under the same conditions ${ }^{21}$. In the present study, QN suppressed these proliferative effects of serotonin. Amine 

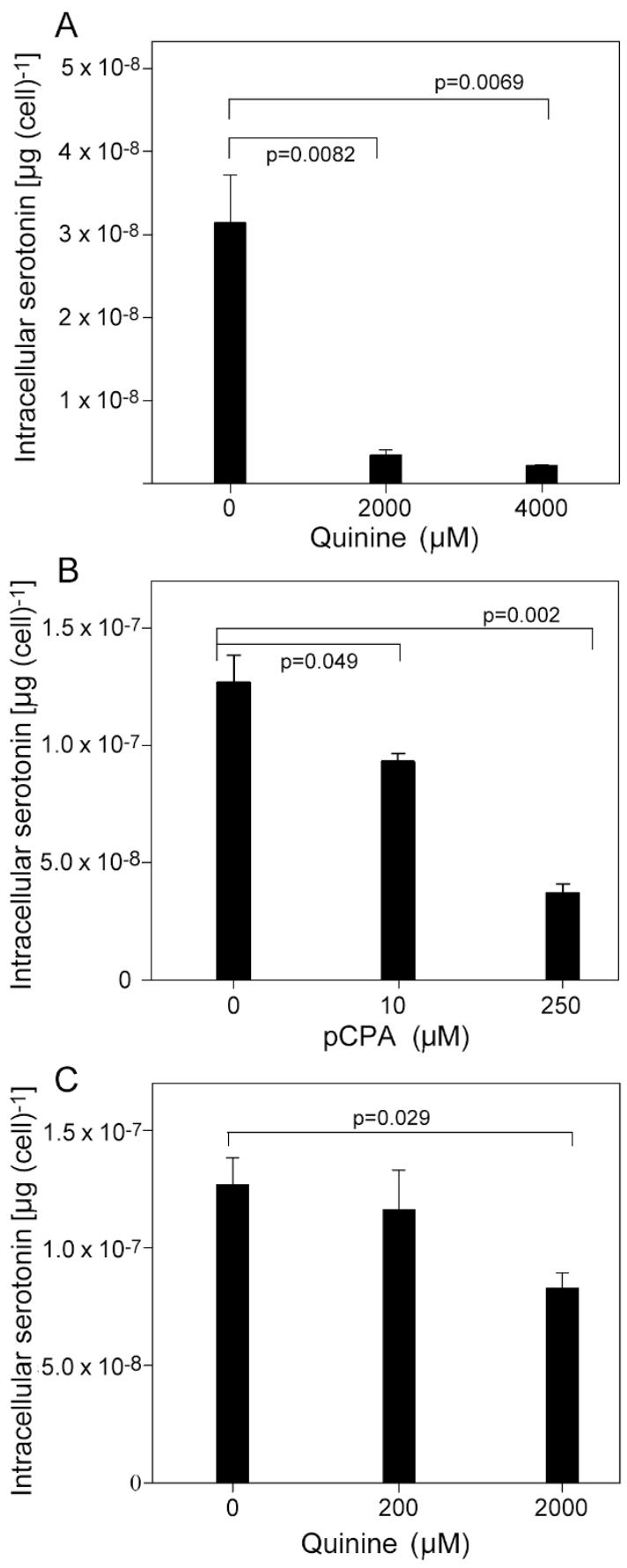

Figure $4 \mid$ Quinine inhibits serotonin production. (A) Yeast cells transformed with pYES-TDC were cultured for $24 \mathrm{~h}$ in the presence of the indicated quinine concentration before determination of cellular serotonin with HPLC-ED. (B) Serotonin was determined in rat RN46A cells after $5 \mathrm{~d}$ culturing with the indicated concentration of the TPH2 inhibitor, pCPA. (C) Serotonin was determined in rat RN46A cells after $5 \mathrm{~d}$ culturing with the indicated concentration of quinine. Mean values are shown \pm SEM from three independent experiments.

alcohol receptors of yeast are poorly understood. In contrast, 5-HT receptors are well described in higher cells, including as therapeutic targets, and previous work indicated that QN inhibits activation of mammalian $5-\mathrm{HT}_{3}$ receptors expressed in Xenopus oocytes or HEK293 cells $^{19,20}$. In addition, QN has been reported to inhibit active serotonin uptake into rat synaptosomes ${ }^{28}$ and to affect serotoninmodulated $\mathrm{K}^{+}$-channels ${ }^{29}$. Here, QN was observed to inhibit calcium signalling at $5-\mathrm{HT}_{2 \mathrm{a} / 2 \mathrm{c}}$ receptors. This is important as $5-\mathrm{HT}_{2}$ receptors are linked to a variety of neuropsychological disorders such as anxiety and mood lowering effects ${ }^{16}$.

In mammals, serotonin production in the central nervous system is rate-limited by the TPH 2 enzyme ${ }^{30}$. The present in vitro assays suggested that QN competes directly with tryptophan for binding to the active site of TPH2, similar to the known competitive TPH2 inhibitor, $\mathrm{pCPA}^{31}$. pCPA potently decreases serotonin production in the brain $^{31}$. The inference that $\mathrm{QN}$, similarly, may have the potential to suppress serotonin production by cells was borne out by analysis of serotonin levels in RN46A cells and, in particular, yeast cells. The strong effect in yeast cells was despite relatively low levels of QN uptake (Fig. $5 a$ ), highlighting the potential potency of QN action in inhibiting serotonin production. However, there was a smaller relative effect on serotonin production in the rat serotonergic cell line RN46A, despite much higher QN uptake. This indicates that the absolute intracellular QN level is not the sole factor that determines inhibition of serotonin production. We propose that another key factor involved here could be cellular tryptophan concentration. Previously we showed that QN and tryptophan compete for uptake via the Tat2p transporter in yeast, leading to tryptophan depletion ${ }^{5}$. The high level of QN uptake in RN46A cells appears to be through a different type of mechanism, as excess tryptophan did not affect QN uptake. This apparent lack of competition for uptake between tryptophan and QN suggests that QN is unlikely to cause the cellular tryptophan depletion in RN46A that occurs in yeast cells. Therefore, the lesser impact of cellular QN on serotonin production in RN46A cells may at least partly be attributable to relatively high tryptophan levels in these cells, as this would balance the competition for $\mathrm{TPH} 2$ binding in favour of the tryptophan substrate (Fig. 6a).

It is evident from the above discussion that the level of competition with tryptophan both for uptake into cells and for TPH2 binding may determine the relative impact of $\mathrm{QN}$ on serotonin production. Competition at the point of uptake, in particular, is likely to vary considerably: between cell types as seen here (e.g. depending on the transporters expressed by cells), and between in vivo physiological environments, as affected by interactions between cells, neurotransmitters and hormones as well as organ type. For example, the level of QN within the brains of patients is thought to be lower than in peripheral tissues due to the blood-brain barrier ${ }^{32}$. Such considerations may mitigate the fact that the effective QN concentrations used in certain of our in vitro experiments with the RN46A cells were higher than the recommended therapeutic dose, approaching QN concentrations that are toxic to mammalian cells. More to the point, the physiological relevance of interactions between QN and tryptophan has already been established in clinical studies, which provided evidence for competition between these molecules in vivo and showed that high plasma tryptophan decreases the incidence of adverse reactions to therapeutic doses of QN in malaria patients ${ }^{7}$. The present work shows how effects of QN on synthesis and function of the major tryptophan metabolite, serotonin, provides a potential explanation for such previous findings. This rationale has further indirect support, from the similarities in the reported adverse neuropsychological effects of QN and of serotonin imbalance, which include tinnitus, loss of appetite, sleep disturbance and anxiety ${ }^{3,4,12,15,16}$. These issues underscore how adherence to the narrow therapeutic index of QN during treatment may avert neurological toxicity and serious adverse effects. Even then, however, several of the effects we report (e.g., Figs. 2, 3, 5) did occur at quinine concentrations that are within the $4-100 \mu \mathrm{M}$ ranges seen in human organs or plasma during quinine treatment $t^{5,7}$. The present work also leaves open the possibility that there are interactions between QN and tryptophan at cellular sites additional to those studied to date, which may have in vivo consequences beyond those suggested. For example, tryptophan is also a precursor in the kynurenine pathway, which is known to play a role in cerebral malaria ${ }^{33,34}$. A high level of QN 

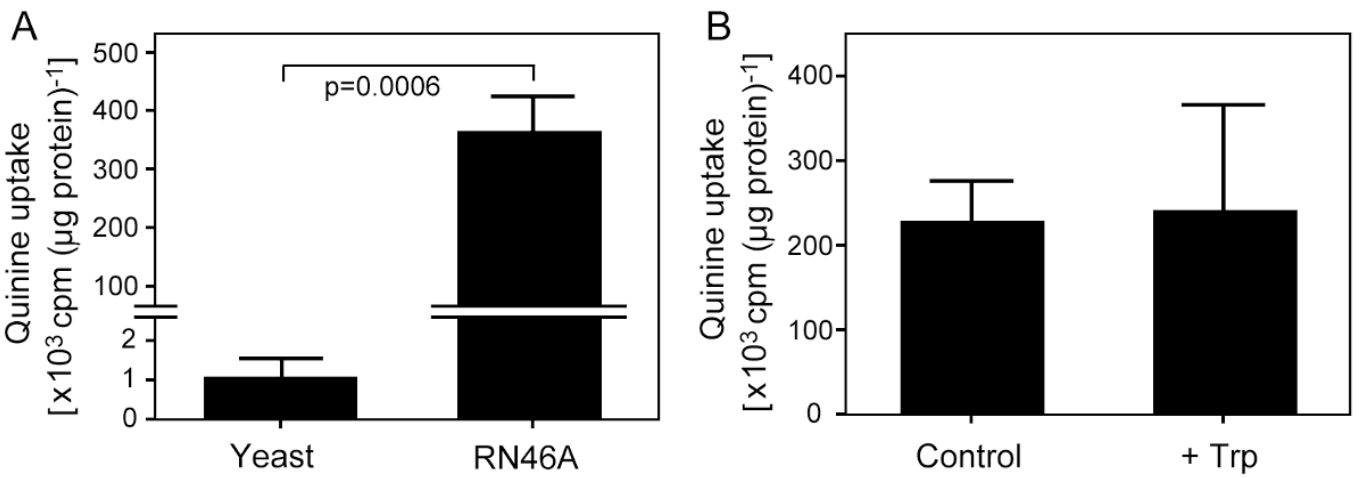

Figure $5 \mid$ Quinine uptake by yeast and rat RN46A cells. (A) Yeast (transformed with pYES-TDC) or RN46A cells were incubated in the presence of $100 \mu \mathrm{M}$ quinine supplemented with $0.9 \mu \mathrm{Ci} \mathrm{ml}^{-1}\left[{ }^{3} \mathrm{H}\right]$-quinine. Cellular radiolabel uptake was determined after $24 \mathrm{~h}$ for yeast or $5 \mathrm{~d}$ for RN46A cells (i.e. the same intervals as for serotonin determination, Fig. 4) and the derived scintillation counts normalized to cellular protein. (B) As in (A) for RN46A cells, but with additional parallel incubations in the presence of $1 \mathrm{mM} \mathrm{L}$-tryptophan. All values are means \pm SEM from three independent experiments.

uptake by mammalian cells, indicated here, may underpin many effects of this drug.

\section{Methods}

Yeast growth. The yeast strains Saccharomyces cerevisiae BY4743 or Candida albicans SC5314 were cultured in Sabouraud's medium containing $30 \mathrm{~g} \mathrm{~L}^{-1}$ maltose, $10 \mathrm{~g} \mathrm{~L}^{-1}$ peptone from casein (Sigma), $3 \mathrm{~g} \mathrm{~L}^{-1}$ yeast extract (Sigma), adjusted to $\mathrm{pH}$ $7.0^{21}$. After $24 \mathrm{~h}$ growth of starter-cultures, strains were inoculated to the same medium in Erlenmeyer flasks and incubated for $4 \mathrm{~h}$ at $34^{\circ} \mathrm{C}$ with orbital shaking at $120 \mathrm{rev} \mathrm{min}{ }^{-1}$. Cultures were then adjusted to $10^{6}$ cells $\mathrm{mL}^{-1}$ in the same medium and distributed in $300 \mu \mathrm{L}$ aliquots per well in 48-well plates (Greiner Bio-One). Wells were supplemented with serotonin hydrochloride (Sigma) or quinine
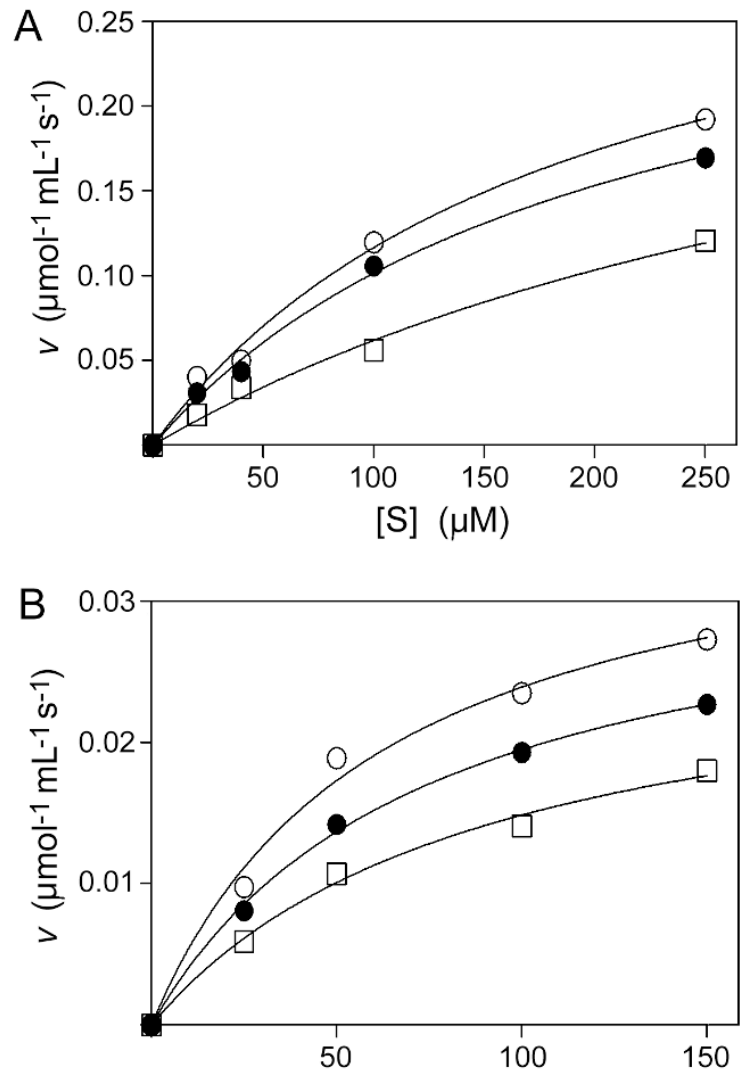

[S] $(\mu \mathrm{M})$ dihydrochloride dihydrate (QN; Sigma) as specified. Growth of the yeasts with shaking at $34^{\circ} \mathrm{C}$ was monitored with a BioTek Power Wave XS2 Microplate Spectrophotometer.

Mammalian cell culture. Human neuroblastoma SHSY5Y cells (a gift from Professor David Kendall, University of Nottingham) and rat raphe RN46A cells (a gift from Dr Scott Whittemore, University of Louisville) were cultured in DMEM-F12 HAM nutrient medium (Sigma) supplemented with $10 \%(\mathrm{v} / \mathrm{v})$ fetal calf serum (Sigma), $2 \mathrm{mM}$ L-glutamine, $100 \mathrm{U} \mathrm{mL}^{-1}$ penicillin and $100 \mu \mathrm{g} \mathrm{mL}^{-1}$ streptomycin ${ }^{35}$. Cells were cultured in $25 \mathrm{~cm}^{2}$ cell culture flasks in $5 \mathrm{~mL}$ DMEM-F12 medium at $36.5^{\circ} \mathrm{C}, 5 \%$ $\mathrm{CO}_{2}$ until confluent. Cells were detached from the bases of flasks with $2 \mathrm{~mL}$ trypsinEDTA solution (Sigma). DMEM-F12 medium $(10 \mathrm{~mL})$ was added to the flask, followed by 7 min centrifugation at $600 \mathrm{~g}$. The cell pellet was resuspended in $10 \mathrm{~mL}$
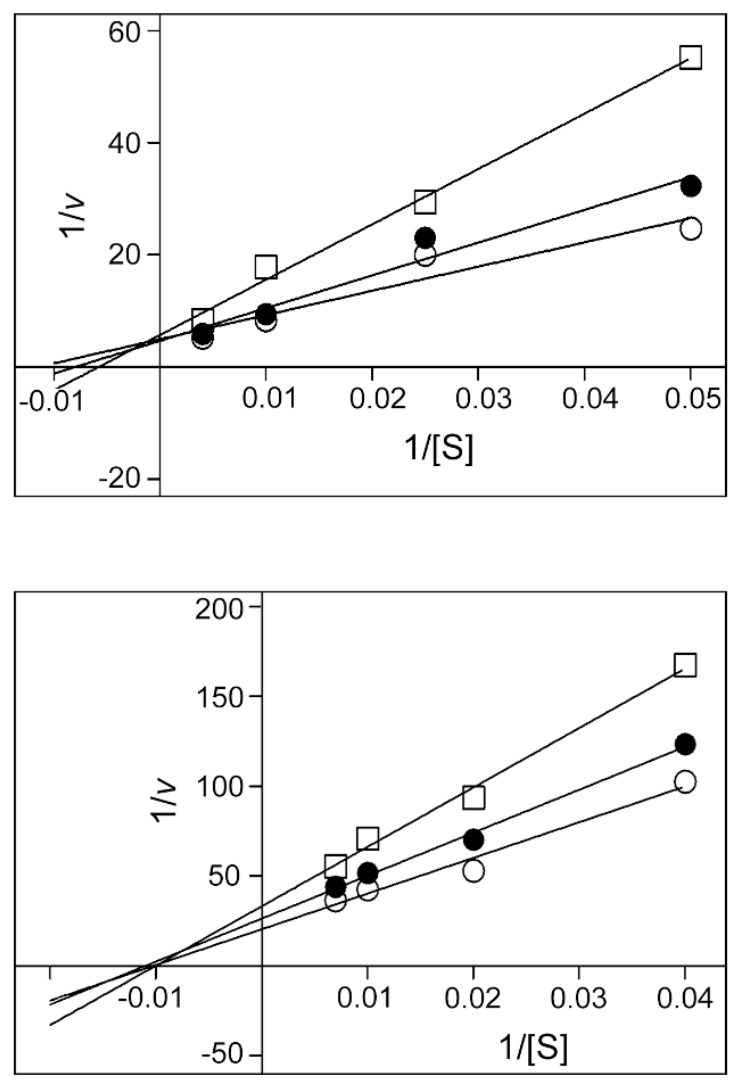

Figure 6 Effect of quinine on in vitro TPH2 activity. (A) Initial rate of activity of the purified catalytic domain of human TPH2 ( $v)$ was assayed in the presence of $0(\bigcirc), 2(\bigcirc)$ or $10(\square) \mathrm{mM}$ QN at different concentrations of the L-tryptophan substrate [S]. Points are means from three replicate determinations of $v$. SEMs were smaller than the dimensions of the symbols. The data are presented as substrate saturation curves (left panel) and Lineweaver-Burk plots (right). (B) As in (A) but where [S] refers to different concentrations of the TPH2 co-factor $6 \mathrm{MePH}_{4}$. 
DMEM-F12. An aliquot $(0.5 \mathrm{~mL})$ of the cell suspension was added to $4.5 \mathrm{~mL}$ DMEM-F12 in $25 \mathrm{~cm}^{2}$ cell culture flasks, and cultured until confluent at $36.5^{\circ} \mathrm{C}$ in $5 \%$ $\mathrm{CO}_{2}$

Mammalian cell proliferation. The assay was adapted from that described previously $^{22}$. From confluent cultures (above), SHSY5Y cells were adjusted to $5 \times$ $10^{5}$ cells $\mathrm{mL}^{-1}$ in DMEM-F12 medium and $100 \mu \mathrm{L}$ aliquots seeded to individual wells of flat-bottomed 96-well plates. Wells were supplemented with serotonin, ketanserin (a selective 5- $\mathrm{HT}_{2}$ receptor antagonist, Sigma) or QN as specified in the results section. Plates were incubated at $36.5^{\circ} \mathrm{C}, 5 \% \mathrm{CO}_{2}$ for $72 \mathrm{~h}$, before cells were detached by addition of $50 \mu \mathrm{L}$ trypsin-EDTA solution. Detached cell mixture was added to $200 \mu \mathrm{L}$ fresh medium in microcentrifuge tubes. Cells were centrifuged $(600 \mathrm{~g}, 7 \mathrm{~min})$ and the supernatant removed by aspiration. Cells were resuspended in $100 \mu \mathrm{L}$ fresh medium and counted using a Neubauer hemocytometer (1/400 square mm, depth $0.1 \mathrm{~mm})$.

Serotonin receptor activity. SHSY5Y cells were cultured in clear-bottomed 96-well black plates (Cellstar) for $48 \mathrm{~h}$ in DMEM-F12 at $36.5^{\circ} \mathrm{C}, 5 \% \mathrm{CO}_{2}$. The medium was then aspirated and $200 \mu \mathrm{L}$ of DMEM-F12, $10 \%(\mathrm{v} / \mathrm{v})$ fetal calf serum, containing $100 \mathrm{U} \mathrm{mL}^{-1}$ penicillin, $100 \mu \mathrm{g} \mathrm{mL}^{-1}$ streptomycin, $1 \mu \mathrm{M}$ FLUO-4 (Invitrogen) and $2.5 \mathrm{mM}$ probenecid (Sigma), were aliquoted to each well. After $45 \mathrm{~min}$ incubation at $30^{\circ} \mathrm{C}, 5 \% \mathrm{CO}_{2}$, cells were washed with HEPES buffered saline (10 mM HEPES, $2 \mathrm{mM}$ sodium pyruvate, $10 \mathrm{mM} \mathrm{D}$-glucose, $0.145 \mathrm{M}$ sodium chloride, $1 \mathrm{mM}$ magnesium sulphate, $5 \mathrm{mM}$ potassium chloride, $1.3 \mathrm{mM}$ calcium chloride, $1.5 \mathrm{mM}$ sodium hydrogen carbonate, pH 7.45) containing $2.5 \mathrm{mM}$ probenecid. Following this, $180 \mu \mathrm{L}$ of HEPES buffered saline containing $2.5 \mathrm{mM}$ probenecid were added to each well. Where specified, the saline was supplemented with ketanserin or QN. After incubation of plates on a hot plate at $30^{\circ} \mathrm{C}$ for $20 \mathrm{~min}$, the cells were examined with a FlexStation3 Microplate Reader (Molecular Devices) using SoftMax ${ }^{\circledR}$ Pro software, with fluorescence from the FLUO-4 probe determined at $485 \mathrm{~nm}$ excitation and $525 \mathrm{~nm}$ emission. Where specified, serotonin $(20 \mu \mathrm{L})$ was added to a final concentration of $10^{-5} \mathrm{M}$

Determination of cellular serotonin. For determinations in S. cerevisiae BY4743 cells were transformed with plasmid pYES-TDC ${ }^{23}$, using the lithium acetate method $^{36}$. Transformant cells were cultured to $\mathrm{OD}_{600} \sim 2.0$ in YNB broth with appropriate selection ${ }^{37}$ before sub-culturing to fresh medium supplemented with or without QN. Cells were harvested for analysis after $24 \mathrm{~h}$ incubation at $30^{\circ} \mathrm{C}$. For RN46A cells, these were seeded from confluent flasks (see above) to fresh medium supplemented with QN or p-chlorophenylalanine (pCPA; Sigma) and incubated for $5 \mathrm{~d}$ at $36.5^{\circ} \mathrm{C}, 5 \% \mathrm{CO}_{2}$. After harvesting by centrifugation, cells were suspended in $0.5 \mathrm{~mL}$ (yeast) or $1 \mathrm{~mL}$ of $0.1 \mathrm{M}$ perchloric acid containing $1.6 \mathrm{mM}$ sodium metabisulphite. Cell lysis of yeast cells was facilitiated by mechanical breakage with glass beads using a Fast Prep-24 MP bead beater. Cell lysates were centrifuged for $3 \mathrm{~min}$ at $15000 \mathrm{~g}$ at $4^{\circ} \mathrm{C}$, and supernatants were stored at $-80^{\circ} \mathrm{C}$ until analysis. Protein was determined with a Bradford assay kit (BioRad). Serotonin was determined using high performance liquid chromatography with electrochemical detection (HPLC-ED) as previously described ${ }^{38}$. In brief, samples were thawed, weighed and sonicated (Soniprep 150: MSE Scientific Instruments; Crawley, UK) for $30 \mathrm{~s}$ in $800 \mu \mathrm{L}$ of $0.05 \mathrm{M}$ perchloric acid containing $1 \mu \mathrm{M}$ sodium metabisulphite, then centrifuged $\left(17,400 \mathrm{~g}, 4^{\circ} \mathrm{C}\right.$ for $20 \mathrm{~min}$; Harrier 18/80: MSE Scientific Instruments; Crawley, UK) and the supernatant filtered $(0.45 \mu \mathrm{m}$ syringe tip filter, Kinesis Ltd; St Neots, UK). Monoamines were separated using a PerkinElmer Series 200 autosampler and Targa C18 $3 \mu \mathrm{m}$ column $(100 \mathrm{~mm} \times 2.1 \mathrm{~mm}$ : Presearch; Basingstoke, UK) and detected at a potential of $+0.59 \mathrm{~V}$ against ISAAC reference electrode by an Antec Intro amperometric detector (Zoeterwoude, The Netherlands). Mobile phase consisting of $20 \mathrm{mM}$ potassium dihydrogen orthophosphate, $20 \mathrm{mM}$ sodium acetate, $8 \mathrm{mM}$ potassium chloride, $0.1 \mathrm{mM}$ disodium ethylenediaminetetraacetic acid (EDTA), $0.16 \mathrm{mM}$ octanesulphonic acid and $10 \% \mathrm{v} / \mathrm{v}$ methanol adjusted to $\mathrm{pH} 3.8-4$ was delivered at $0.2 \mathrm{~mL} \mathrm{~min}^{-1}$ by an isocratic pump (Dionex P680) and quantification used Galaxie (version 1.8) software. (Antec). The lower detection limit was 1 pmol per $20 \mu \mathrm{L}$ sample.

Quinine uptake. S. cerevisiae BY4743 transformed with plasmid pYES-TDC, or RN46A cells were cultured as described above. Media were supplemented with $0.1 \mathrm{mM}$ QN, and $\left[9-{ }^{3} \mathrm{H}\right]-\mathrm{QN}$ (American Radiolabeled Chemicals) to a final activity of $0.9 \mu \mathrm{Ci} \mathrm{ml}^{-1}\left[10-20 \mathrm{Ci}(\mathrm{mmol} \mathrm{QN})^{-1}\right]$. Where indicated, L-tryptophan was added to a final concentration of $1 \mathrm{mM}$. After the same incubation times with QN as used above for determination of cellular serotonin ( $24 \mathrm{~h}$ for yeast, $5 \mathrm{~d}$ for RN46A), cells were washed and resuspended in phosphate buffered saline before splitting aliquots for transfer to scintillation vials or retention for protein determination. Cellassociated radioactivity was quantified in a liquid scintillation counter (2250CA Packard Tri-carb) and the readings normalized to protein content, determined as described above.

TPH2 activity. A purified catalytic domain of human TPH $2{ }^{24}$ was assayed for activity as described previously ${ }^{24,39}$. The assay buffer comprised $200 \mathrm{mM}$ ammonium sulphate, $7 \mathrm{mM}$ DTT, $25 \mu \mathrm{g} \mathrm{mL}^{-1}$ catalase, $25 \mu \mathrm{M}$ ferrous ammonium sulphate, $50 \mathrm{mM}$ MES, pH 7.0, $150 \mu \mathrm{M}$ 6-methyltetrahydropterin $\left(6 \mathrm{MePH}_{4}\right)($ Sigma $), 25 \mathrm{nM}$ TPH2 enzyme and $20 \mu \mathrm{M}$ tryptophan. Where specified, tryptophan $(0.02-0.25 \mathrm{mM})$ or $6 \mathrm{MePH}_{4}(0.025-0.15 \mathrm{mM})$ concentrations were varied, and/or the assay buffer was supplemented with QN. Enzyme activity was quantified with fluorescence spectrophotometry (Cary Eclipse Varian) using a $4 \mathrm{~mm}$ quartz cuvette, $300 \mathrm{~nm}$ excitation, $330 \mathrm{~nm}$ emission, with a $5 \mathrm{~nm}$ band pass.

1. Vitoria, M. et al. The global fight against HIV/AIDS, tuberculosis and malaria current status and future perspectives. Am J Clin Pathol 131, 844-848 (2009).

2. Ménard, D. et al. Global analysis of Plasmodium falciparum $\mathrm{Na}^{+} / \mathrm{H}^{+}$exchanger ( $p$ fnhe-1) allele polymorphism and its usefulness as a marker of in vitro resistance to quinine. Int J Parasitol 3, 8-19 (2013).

3. Berman, J. Toxicity of commonly-used antimalarial drugs. Travel Med Infect Dis 2, 171-184 (2004)

4. Taylor, W. R. \& White, N. J. Antimalarial drug toxicity: a review. Drug Safety 27, 25-61 (2004).

5. Khozoie, C., Pleass, R. J. \& Avery, S. V. The antimalarial drug quinine disrupts Tat2p-mediated tryptophan transport and causes tryptophan starvation. J Biol Chem 284, 17968-17974 (2009).

6. dos Santos, S. C. \& Sá-Correia, I. A genome-wide screen identifies yeast genes required for protection against or enhanced cytotoxicity of the antimalarial drug quinine. Mol Genet Genomics 286, 333-346 (2011).

7. Islahudin, F., Pleass, R. J., Avery, S. V. \& Ting, K.-N. Quinine interactions with tryptophan and tyrosine in malaria patients, and implications for quinine responses in the clinical setting. J Antimicrob Chemother 67, 2501-2505 (2012).

8. Neumeister, A. et al. Effects of tryptophan depletion in drug-free depressed patients who responded to total sleep deprivation. Arch Gen Psych 55, 167-172 (1998).

9. Badawy, A. A. B., Morgan, C. J., Llewelyn, M. B., Albuquerque, S. R. J. \& Farmer, A. Heterogeneity of serum tryptophan concentration and availability to the brain in patients with the chronic fatigue syndrome. J Psychopharmacol 19, 385-391 (2005).

10. Mishra, S. K. \& Newton, C. R. J. C. Diagnosis and management of the neurological complications of falciparum malaria. Nat Rev Neurol 5, 189-198 (2009).

11. Toovey, S. Mefloquine neurotoxicity: A literature review. Travel Med Infect Dis 7, 2-6 (2009).

12. Rolling, T. et al. Artesunate versus quinine in the treatment of severe imported malaria: comparative analysis of adverse events focussing on delayed haemolysis Malaria J 12, Art. no. 241 (2013).

13. Moja, E. A., Cipolla, P., Castoldi, D. \& Tofanetti, O. Dose-response decrease in plasma tryptophan and in brain tryptophan and serotonin after tryptophan-free amino acid mixtures in rats. Life Sci 44, 971-976 (1989).

14. Nordquist, N. \& Oreland, L. Serotonin, genetic variability, behaviour, and psychiatric disorders - a review. Ups J Med Sci 115, 2-10 (2010).

15. Tost, H. \& Meyer-Lindenberg, A. I fear for you: A role for serotonin in moral behavior. Proc Natl Acad Sci USA 107, 17071-17072 (2010).

16. Pytliak, M., Vargova, V., Mechirova, V. \& Felsoci, M. Serotonin receptors: From molecular biology to clinical applications. Physiol Res 60, 15-25 (2011).

17. Silber, B. Y. \& Schmitt, J. A. J. Effects of tryptophan loading on human cognition, mood, and sleep. Neurosci Biobehav Rev 34, 387-407 (2010).

18. Bell, C., Abrams, J. \& Nutt, D. Tryptophan depletion and its implication for psychiatry. Br J Psych 178, 399-405 (2001).

19. Thompson, A. J. \& Lummis, S. C. R. Antimalarial drugs inhibit human $5-\mathrm{HT}_{3}$ and $\mathrm{GABA}_{\mathrm{A}}$ but not GABA $\mathrm{C}$ receptors. Brit J Pharmacol 153, 1686-1696 (2008).

20. Thompson, A. J., Lochner, M. \& Lummis, S. C. R. The antimalarial drugs quinine, chloroquine and mefloquine are antagonists at $5-\mathrm{HT}_{3}$ receptors. Brit J Pharmacol 151, 666-677 (2007).

21. Malikina, K. D., Shishov, V. A., Chuvelev, D. I., Kudrin, V. S. \& Oleskin, A. V. Regulatory role of monoamine neurotransmitters in Saccharomyces cerevisiae cells. Appl Biochem Microbiol 46, 620-625 (2010).

22. Drozdov, I. et al. Autoregulatory effects of serotonin on proliferation and signalling pathways in lung and small intestine neuroendocrine tumor cell lines. Cancer 115, 4934-4945 (2009).

23. Park, M., Kang, K., Park, S. \& Back, K. Conversion of 5-hydroxytryptophan into serotonin by tryptophan decarboxylase in plants, Escherichia coli and yeast. Biosci Biotechnol Biochem 72, 2456-2458 (2008).

24. Windahl, S. M., Boesen, J., Karlsen, P. E. \& Christensen, H. E. M. Expression, purification and enzymatic characterization of the catalytic domains of human tryptophan hydroxylase isoforms. J Prot 28, 400-406 (2009).

25. Boyer, E. W. \& Shannon, M. The serotonin syndrome. New Engl J Med 352, 1112-1120 (2005).

26. Siddiqui, E. J., Shabbir, M., Mikhailidis, D. P., Thompson, C. S. \& Mumtaz, F. H. The role of serotonin (5-hydroxytryptamine $1 \mathrm{~A}$ and $1 \mathrm{~B})$ receptors in prostate cancer cell proliferation. J Urol 176, 1648-1653 (2006).

27. Soll, C. et al. Serotonin promotes tumor growth in human hepatocellular cancer. Hepatology 51, 1244-1254 (2010)

28. Clement, E. M., Grahame-Smith, D. G. \& Elliott, J. M. Investigation of the presynaptic effects of quinine and quinidine on the release and uptake of monoamines in rat brain tissue. Neuropharmacol 37, 945-951 (1998).

29. Wang, H. \& Grahame-Smith, D. G. The effects of rubidium, caesium and quinine on 5-HT-mediated behaviour in rat and mouse - 3. Quinine. Neuropharmacol 31, 425-431 (1992).

30. Zhang, X., Beaulieu, J. M., Sotnikova, T. D., Gainetdinov, R. R. \& Caron, M. G. Tryptophan hydroxylase 2 controls brain serotonin synthesis. Science 305, 217 (2004). 
31. Stokes, A. H. et al. p-Ethynylphenylalanine: A potent inhibitor. J Neurochem 74, 2067-2073 (2000).

32. Vieira, J. L. F., Gomes, A. L. S., Borges, L. M. G. \& Guimaraes, E. R. Relationship between plasma and red blood cell concentrations of quinine in Brazilian children with uncomplicated Plasmodium falciparum malaria on oral therapy. Rev. Inst. Med. Trop. S. Paulo 51, 109-110 (2009).

33. Sanni, L. A. et al. Dramatic changes in oxidative tryptophan metabolism along the kynurenine pathway in experimental cerebral and noncerebral malaria. $\mathrm{Am}$ Pathol 152, 611-619 (1998).

34. Clark, C. J. et al. Prolonged survival of a murine model of cerebral malaria by kynurenine pathway inhibition. Infect Immun 73, 5249-5251 (2005).

35. Koldzic-Zivanovic, N., Seitz, P. K., Cunningham, K. A. \& Hughes, T. K. Serotonin regulation of serotonin uptake in RN46A cells. Cell Mol Neurobiol 26, 979-987 (2006)

36. Gietz, R. D. \& Woods, R. A. Transformation of yeast by lithium acetate/singlestranded carrier DNA/polyethylene glycol method. Methods Enzymol 350, 87-96 (2002).

37. Alhebshi, A., Sideri, T. C., Holland, S. L. \& Avery, S. V. The essential iron-sulfur protein Rlil is an important target accounting for inhibition of cell growth by reactive oxygen species. Mol Biol Cell 23, 3582-3590 (2012).

38. King, M. V., Spicer, C. H., Sleight, A. J., Marsden, C. A. \& Fone, K. C. F. Impact of regional 5-HT depletion on the cognitive enhancing effects of a typical 5-ht 6 receptor antagonist, Ro 04-6790, in the Novel Object Discrimination task. Psychopharmacol 202, 111-123 (2009).

39. Moran, G. R. \& Fitzpatrick, P. F. A continuous fluorescence assay for tryptophan hydroxylase. Anal Biochem 266, 148-152 (1999).

\section{Acknowledgments}

The authors thank Scott Whittemore (University of Louisville) for rat raphe RN46A cells, Kyoungwhan Back (Chonnam National University) for the pYES-TDC plasmid, David Kendall (University of Nottingham) for SHSY5Y cells, and Tim Self (University of Nottingham) for help with calcium imaging. This study was funded by the University of Nottingham (MIDAS scheme) and the Ministry of Higher Education Malaysia.

\section{Author contributions}

F.I. and S.M.T. performed the experiments. F.I., S.M.T., I.R.M., R.J.P., K.N.T. and S.V.A. designed the experiments. K.S. performed the serotonin analyses. F.I., K.N.T. and S.V.A. prepared the manuscript. I.R.M., K.C.F.F., H.E.M.C. and R.J.P. provided valuable materials and conceptual input and also reviewed the manuscript.

\section{Additional information}

Supplementary information accompanies this paper at http://www.nature.com/ scientificreports

Competing financial interests: The authors declare no competing financial interests. How to cite this article: Islahudin, F. et al. The antimalarial drug quinine interferes with serotonin biosynthesis and action. Sci. Rep. 4, 3618; DOI:10.1038/srep03618 (2014). To view a copy of this license, visit http://creativecommons.org/licenses/by/3.0 